\title{
Alternative strategy for manufacturing of all-solid-state reference electrodes for potentiometry
}

\author{
J. C. B. Fernandes and E. V. Heinke \\ The Municipal University of São Caetano do Sul, USCS, Centre Campus, 50, Santo Antônio Street, 09521-160, \\ São Caetano do Sul - SP, Brazil \\ Correspondence to: J. C. B. Fernandes (jcbastos@uscs.edu.br, jcnandes@gmail.com)
}

Received: 9 October 2014 - Revised: 9 January 2015 - Accepted: 18 January 2015 - Published: 12 February 2015

\begin{abstract}
This paper presents an alternative strategy for manufacturing solid-state reference electrodes based on particles of graphite/silver/silver chloride synthesized by electroless deposition of metallic silver and silver chloride on graphite powder. Two kinds of reference electrodes were manufactured by mixing these particles with epoxy resin and hardener: quasi-reference and all-solid-state containing salts of alkaline or alkaline earth metals. All-solid-state reference electrodes can be sterilized with high-pressure saturated steam at $394.15 \mathrm{~K}\left(121^{\circ} \mathrm{C}\right)$ using an autoclave. These electrodes presented a stable potential between $\mathrm{pH} 2$ and 11 . The electrode surface was characterized by scanning electron microscopy and showed the presence of silver and salt particles. The size of the silver particles was less than $2.5 \mu \mathrm{m}$. We successfully applied the all-solid state reference electrodes in potentiometric cells to measure $\mathrm{pH}$ and potassium ions in complex matrix by direct potentiometry and Lascorbic acid by potentiometric titration.
\end{abstract}

\section{Introduction}

Reference electrodes have been the Achilles heel for many electrochemical systems, especially for potentiometric techniques. A good reference electrode for potentiometric measurements must maintain a constant comparative potential value and cannot respond to the presence of chloride ions in the sample solution. The most common reference electrodes have a plastic or glass body for storing the saturated solution of potassium chloride called electrolyte. A silver wire coated with silver chloride, a paste of mercury and mercury chloride (calomel), or a paste of thallium, mercury and thallium chloride (Thalamid) is dipped into this solution (Guth et al., 2009).

The calomel electrode has better technical characteristics than reference electrodes based on silver/silver chloride $\left(\mathrm{Ag} / \mathrm{AgCl}, \mathrm{Cl}^{-}\right)$. The potential drift of the calomel electrode is low and not even light influences this electrode. However, the calomel electrode cannot be used in temperatures above $353.15 \mathrm{~K}\left(80^{\circ} \mathrm{C}\right)$ because it presents hysteresis at these temperatures (Janz and Taniguchi, 1953). Like Thalamid electrodes, calomel electrodes will probably be banned in the next years, because mercury is very hazardous to the envi- ronment. Therefore, reference electrodes based on $\mathrm{Ag} / \mathrm{AgCl}$, $\mathrm{Cl}^{-}$may be the most popular in the future.

Conventionally, reference electrodes based on $\mathrm{Ag} / \mathrm{AgCl}$, $\mathrm{Cl}^{-}$are produced by electroplating of silver on the surface of a platinum wire (5-6h) and $15-25 w / w \%$ of the silver is converted to silver chloride by anodic treatment with hydrochloric acid for $30 \mathrm{~min}$ (Janz and Taniguchi, 1953).

Many patents (Jayaweera et al., 1995; Shin et al., 2003; Sorensen and Zachau-Christiansen, 2004; Cha et al., 2005; Rodes, 2008) and articles (Suzuki et al., 1998, 1999; Tymecki et al., 2004; Guth et al., 2009; Rius-Ruiz et al., 2011; Valdés-Ramírez et al., 2011) reported innumerable strategies for construction of solid-state reference electrodes. Shin et al. (2003) developed a reference electrode by depositing metal (Ag, Pt, $\mathrm{Au}$ or $\mathrm{Cu}$ ) and insoluble salt (silver halide) in layers on a substrate using thick film. The inner reference solution was in the state of hydrogel with an insulating film separating it from the aqueous solution. Timecki et al. (2004) produced a miniaturized reference electrode employing a sandwich of three pastes: Ag (725A-6S-54 from Acheson) as transducer, $\mathrm{Ag} / \mathrm{AgCl}$ as the sensing layer and potassium chloride $(\mathrm{KCl})$ as the protective layer. Carbon nan- 
otubes were also used as a transducer from a polyacrylate membrane containing $\mathrm{Ag} / \mathrm{AgCl}, \mathrm{Cl}^{-}$system (Rius-Ruiz et al., 2011). Thin film technology has also been used for microfabrication of reference electrodes (Suzuki et al., 1999). Valdés-Ramírez et al. (2011) electrodeposited silver and silver chloride on a graphite-epoxy electrode surface under adequate conditions of electrical potential and electrical current.

On the one hand, the large number of layers may complicate the miniaturization by techniques of thin film or of thick film. On the other hand, reference electrodes manufactured by electroplating using a potentiostat have an $\mathrm{Ag} / \mathrm{AgCl}$ layer thickness that may be destructed by friction.

Other problems of reference electrodes include the following: classical reference electrodes can develop a potential due to outflow of the inner electrolyte through the liquid connection. One strategy to overcome this problem is to use gel electrolytes. However, gels of agar-agar or gelatin are unstable with temperature variation and reference electrodes with these gels cannot be sterilized into autoclave. Since, advanced gels such as polyvinyl acrylamide, polyvinyl alcohol, hydroxymethyl cellulose and hydroxyethyl cellulose have higher temperature resistance, these gels can be used alternatively. However, advanced gels have lower solubility for salts, therefore, a potential drift can be developed if chloride ions are in the sample solution (Guth et al., 2009).

The aim of this work is to propose an alternative strategy for manufacturing of all-solid state reference electrodes by developing silver and silver chloride particles that are deposited on graphite powder by electroless deposition without need of electroplating equipment.

\section{Experimental}

\subsection{Materials}

Trizma base buffer (minimum 99.9\%), silica gel $(60 \mu \mathrm{m}$ size), valinomycin and bis-2-ethylhexyl adipate were purchased from Sigma-Aldrich. Potassium tetraoxalate dehydrate $(\mathrm{pH}=1.679)$, potassium hydrogen phthalate ( $\mathrm{pH}=4.008)$, potassium dihydrogen phosphate, sodium hydrogen phosphate $(\mathrm{pH}=6.865)$, sodium tetraborate $(\mathrm{pH}=9.180)$ and calcium hydroxide $(\mathrm{pH}=12.454)$ were used for preparing primary standard $\mathrm{pH}$ solutions at $298.15 \mathrm{~K}\left(25^{\circ} \mathrm{C}\right)$. These reagents were also purchased from Sigma-Aldrich. High molecular weight poly(vinyl)chloride (PVC) was donated by Solvay-Brazil. BQ164 ink based on $\mathrm{Ag} / \mathrm{AgCl}$ particles was acquired from DuPont Microcircuit Materials. Other reagents, such as L-ascorbic acid, potassium chloride, anhydrous sodium sulfate, potassium iodide, barium chloride, potassium hydroxide, ammonium hydroxide, sodium hydroxide, silver nitrate, glucose, sodium fluoride, hydrochloric acid, sulfuric acid, propanone, tetrahydrofuran and graphite powder $(50-300 \mu \mathrm{m}$ size) were analytical grade reagents. We also acquired Brascola's epoxy resin and poly(imide) of the trademark Araldite.
Noncarbonated sports drinks and syrups were obtained from local markets or pharmacies. All solutions were prepared using distilled water.

\subsection{Instrumentation and protocols}

All potentiometric measurements were carried out using an ion analyser HI 223 model from Hanna instruments. All reference electrodes were characterized analysing their potential response against a commercial reference electrode ( $\mathrm{Ag} / \mathrm{AgCl}), \mathrm{R} 684-105$ model from Analion. In our experiments, the reference electrolyte was potassium chloride solution at $3 \mathrm{~mol} \mathrm{~L}^{-1}$. Potentiometric cells with a $\mathrm{pH}$ single-rod measuring cell (HI-1131P model) or a homemade potassium ion selective electrode (ISE-K) were used for testing the allsolid-state reference electrodes in real samples for direct potentiometry. The ISE-K was prepared according to previous work (Fernandes et al., 2000).

Potentiometric titrations of L-ascorbic acid were made with a mercury indicator electrode. The mercury electrode was prepared according to literature (Riyazuddin and Nazer, 1997), with some adaptations. We used a copper rod of $2 \mathrm{~mm}$ diameter and $5 \mathrm{~cm}$ length. The copper rod was immersed in a solution of epoxy : polyimide (weight proportion, $3: 1$ ) in propanone to form a film that electrically isolates the copper from the environment. The bottom of the copper rod was trimmed to remove the cured resin. Afterwards, this rod was polished with abrasive papers. The copper electrode was immersed in acid solution of mercury (II) nitrate at $0.02 \mathrm{~mol} \mathrm{~L}^{-1}$ for $10 \mathrm{~min}$ for deposition of the metallic mercury on the copper surface. The electrode was washed with distilled water and polished using a filter paper with a pore size of $8 \mu \mathrm{m}$.

Morphological studies of the surface were performed using FEI Quanta FEG 250 scanning electron microscopy. The samples were coated with a thin layer of gold $\mathrm{Au}$ ) by a sputter coater to reduce charging.

\subsubsection{Synthesis of metallic silver and silver chloride particles on graphite powder}

Metallic silver particles were obtained by electroless deposition using silver nitrate, ammonia, potassium hydroxide and glucose solutions (Koura, 1990). For electroless deposition of silver and silver chloride particles, silver nitrate solutions concentrated between 0.04 and $8.00 \mathrm{~mol} \mathrm{~L}^{-1}$ were used. The concentrations of the other solutions were estimated by the stoichiometry of the reactions according to the following chemical equations, from (1) to (3). 


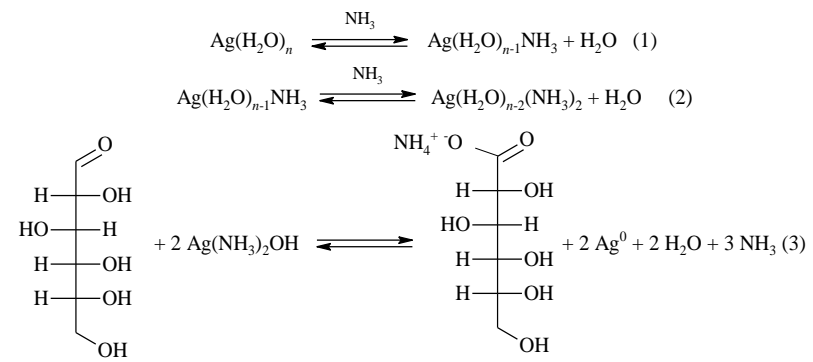

Silver chloride particles were obtained using only silver nitrate and potassium chloride solutions. Electroless silver deposition was carried out at $283.15 \mathrm{~K}\left(10^{\circ} \mathrm{C}\right)$ and silver chloride precipitation at room temperature.

For preparation of the silver particles on graphite, about $8.00 \mathrm{~g}$ of graphite powder were weighed. The graphite powder was put uniformly into a glass container of $2 \mathrm{~L}$ to form a layer with thickness $<1 \mathrm{~mm}$. We carefully added $10 \mathrm{~mL}$ of silver nitrate solution at $8.0 \mathrm{~mol} \mathrm{~L}^{-1}, 10 \mathrm{~mL}$ of ammonium hydroxide at $16.0 \mathrm{~mol} \mathrm{~L}^{-1}, 32 \mathrm{~mL}$ of glucose solution at $2.1 \mathrm{~mol} \mathrm{~L}^{-1}$ and $10 \mathrm{~mL}$ of potassium hydroxide solution at $4.0 \mathrm{~mol} \mathrm{~L}^{-1}$ to the graphite powder without stirring.

A similar procedure was used for deposition of silver chloride particles on the graphite/silver powder. In this case, we weighed $8.00 \mathrm{~g}$ of graphite/silver powder and put it into a glass container of $2 \mathrm{~L}$. Afterwards, we added $100 \mathrm{~mL}$ of silver nitrate solution and $100 \mathrm{~mL}$ of potassium chloride solution (both $0.4 \mathrm{~mol} \mathrm{~L}^{-1}$ ) into the glass container.

The graphite/silver/silver chloride particles were washed with cold distilled water and filtered under vacuum. The powder was dried in an oven at $313.15 \mathrm{~K}\left(40^{\circ} \mathrm{C}\right)$ for $1 \mathrm{~h}$. The graphite/silver/silver chloride particles were stocked in a dark glass flask to avoid decomposition by action of light.

\subsubsection{Preparation of the quasi-reference electrodes}

We manufactured quasi-reference electrodes mixing the particles of graphite/silver/silver chloride with epoxy resin and hardener $(3: 1)$. The weight of these particles was maintained constant at $100 \mathrm{mg}$ while the weight of epoxy resin plus hardener $(3: 1)$ was changed to obtain a percentage of graphite/silver/silver chloride particles of between 15 and $75 \% \mathrm{w} / \mathrm{w}$. We added $2 \mathrm{~mL}$ of propanone to the paste in order to dissolve the adhesive. The paste was homogenized in a glass mortar with a glass pestle. Afterwards, propanone was left to evaporate until the mixture reached the proper viscosity to be transferred to a tube with a $3 \mathrm{~mm}$ inner diameter and $5 \mathrm{~cm}$ of length.

Finally, a copper wire was dipped into a mercury (II) nitrate solution $\left(0.02 \mathrm{~mol} \mathrm{~L}^{-1}\right)$ to produce a thin layer of metallic mercury on its surface. Mercury layer avoids the copper oxidation by the silver chloride. The wire was inserted into the paste to obtain electrical contact.
All electrodes were left to dry for $8 \mathrm{~h}$ at $363.15 \mathrm{~K}\left(90^{\circ} \mathrm{C}\right)$. The surface of the reference electrodes was polished with abrasive papers of 150-2 000 meshes before use.

We also verified the use a commercial ink (BQ164, see Sect. 2.1) for manufacturing potentiometric reference electrodes. These electrodes were fabricated in the same manner described before.

\subsubsection{Preparation of the all-solid-state reference electrodes}

The protocol for manufacturing all-solid-state reference electrodes was similar to the one described previously. The amount of epoxy resin plus hardener was maintained constant in a proportion of $3: 1$ in terms of weights. The concentration of graphite/silver/silver chloride particles was about $45 \% \mathrm{w} / w$. Salts of halogens $\left(\mathrm{F}^{-}, \mathrm{Cl}^{-}\right.$and $\left.\mathrm{I}^{-}\right)$with cations of alkaline metals $\left(\mathrm{Na}^{+}\right.$and $\left.\mathrm{K}^{+}\right)$or alkaline earth metals $\left(\mathrm{Ba}^{2+}\right)$ were added to the paste at concentrations of between 1.5 and $3.0 \mathrm{~mol} \mathrm{~kg}^{-1}$. Sulfate anion $\left(\mathrm{SO}_{4}^{2-}\right)$ was used in some formulations as well. Silica $\left(\mathrm{SiO}_{2}\right)$ was studied for reducing the surface tension of the reference electrode. Table 1 shows the amount used in the preparation of all-solid-state reference electrodes with additives.

\subsubsection{Characterization of the reference electrodes}

Standard solutions of chloride ions $(\mathrm{KCl})$ from $1 \times 10^{-6}$ to $1 \times 10^{-1} \mathrm{~mol} \mathrm{~L}^{-1}$ were prepared in $0.2 \mathrm{~mol} \mathrm{~L}^{-1}$ Trizma sulfate buffer at $\mathrm{pH} 7.0$ to maintain a constant ionic strength. Manufactured reference electrodes were characterized against a conventional reference electrode based on $\mathrm{Ag} / \mathrm{AgCl}, 3 \mathrm{~mol} \mathrm{~L}^{-1} \mathrm{KCl}$.

The effect of the $\mathrm{pH}$ on all-solid-state reference electrodes was studied in the $\mathrm{pH}$ range from 1 to 13 . Primary and secondary standard solutions of $\mathrm{pH}$ were prepared according to the literature (Weast, 1998) and employed in these studies.

The leaching out effect of salts from an all-solid-state reference electrode was studied maintaining the reference electrode with $3.0 \mathrm{~mol} \mathrm{~kg}^{-1}$ of $\mathrm{KCl}$ continuously immersed in $1 \mathrm{~mL}$ of deionized water during 20 days. Afterwards, the potassium chloride content of storage water was analysed by gravimetric method using a silver nitrate solution $0.5 \mathrm{~mol} \mathrm{~L}^{-1}$ as a precipitating agent.

A potentiometric cell for potassium ions (ISE-K) based on valinomycin as an ionophore against an all-solid-state reference electrode was used in real samples. The potentiometric cell was calibrated with standard solutions of potassium ions (KCl) from $1 \times 10^{-4}$ to $1 \times 10^{-1} \mathrm{~mol} \mathrm{~L}^{-1}$. These standard solutions and the samples of the noncarbonated sports drinks and syrups were also diluted in $0.2 \mathrm{~mol} \mathrm{~L}^{-1}$ Trizma sulfate buffer at $\mathrm{pH} 7.0$.

Potentiometric titrations of L-ascorbic acid were studied to verify the sensitivity of a redox substance on all-solidstate reference electrodes using an indicator electrode of mer- 
Table 1. Formulations of the all-solid-state reference electrodes (ASSREs).

\begin{tabular}{|c|c|c|c|c|}
\hline ASSREs & $\begin{array}{l}\mathrm{C}_{\text {graphite }} / \mathrm{Ag} / \mathrm{AgCl} \\
\text { particles } \quad(\mathrm{mg})\end{array}$ & $\begin{array}{r}\text { Epoxy resin } \\
(\mathrm{mg})\end{array}$ & $\begin{array}{r}\text { Hardener } \\
(\mathrm{mg})\end{array}$ & $\begin{array}{r}\text { Salt } \\
(\mathrm{mg})\end{array}$ \\
\hline $\begin{array}{l}\mathrm{C}_{\text {graphite }} / \mathrm{Ag} / \mathrm{AgCl} \text {, } \\
3.0 \mathrm{~mol} \mathrm{~kg}^{-1} \mathrm{KCl}\end{array}$ & 150.0 & 91.6 & 30.5 & $60.7(\mathrm{KCl})$ \\
\hline $\begin{array}{l}\mathrm{C}_{\text {graphite }} / \mathrm{Ag} / \mathrm{AgCl} \text {, } \\
1.5 \mathrm{~mol} \mathrm{~kg}^{-1} \\
\mathrm{KCl}: \mathrm{SiO}_{2}\end{array}$ & 150.0 & 91.6 & 30.5 & $30.3(\mathrm{KCl}) 30.3\left(\mathrm{SiO}_{2}\right)$ \\
\hline $\begin{array}{l}\mathrm{C}_{\text {graphite }} / \mathrm{Ag} / \mathrm{AgCl}, \\
1.5 \mathrm{~mol} \mathrm{~kg}^{-1} \mathrm{BaCl}_{2}\end{array}$ & 228.4 & 91.6 & 30.5 & $128.4\left(\mathrm{BaCl}_{2}\right)$ \\
\hline $\begin{array}{l}\mathrm{C}_{\text {graphite }} / \mathrm{Ag} / \mathrm{AgCl}, \\
3.0 \mathrm{~mol} \mathrm{~kg}^{-1} \mathrm{Na}_{2} \mathrm{SO}_{4}\end{array}$ & 264.9 & 91.6 & 30.5 & $164.9\left(\mathrm{Na}_{2} \mathrm{SO}_{4}\right)$ \\
\hline $\begin{array}{l}\mathrm{C}_{\text {graphite }} / \mathrm{Ag} / \mathrm{AgCl} \text {, } \\
3.0 \mathrm{~mol} \mathrm{~kg}^{-1} \mathrm{KI}\end{array}$ & 320.3 & 91.6 & 30.5 & $220.3(\mathrm{KI})$ \\
\hline $\begin{array}{l}\mathrm{C}_{\text {graphite }} / \mathrm{Ag} / \mathrm{AgCl} \text {, } \\
3.0 \mathrm{~mol} \mathrm{~kg}^{-1} \mathrm{NaF}\end{array}$ & 132.0 & 91.6 & 30.5 & $32.0(\mathrm{NaF})$ \\
\hline
\end{tabular}

cury $(\mathrm{Hg})$. A weight of L-ascorbic acid of between 7.5 and $15.0 \mathrm{mg}$ was weighed in a beaker $(50 \mathrm{~mL})$ with an analytical balance. We added $30 \mathrm{~mL}$ of distilled water, $500 \mu \mathrm{L}$ of ammonium thiocyanate at $0.1 \mathrm{~mol} \mathrm{~L}^{-1}$ and $500 \mu \mathrm{L}$ of sodium acetate/acetic acid buffer solution ( $\mathrm{pH} 4.7 / 1 \mathrm{~mol} \mathrm{~L}^{-1}$ ) to the beaker. We titrated the L-ascorbic acid with a copper sulfate solution at $0.0125 \mathrm{~mol} \mathrm{~L}^{-1}$ as titrant using a burette of $10000 \mathrm{~mL}$.

All-solid-state reference electrodes were sterilized by high-pressure saturated steam at $394.15 \mathrm{~K}\left(121^{\circ} \mathrm{C}\right)$ using an autoclave during $15 \mathrm{~min}$ in order to verify its resistance to temperature and pressure.

\section{Results and discussion}

Among the strategies for manufacturing reference electrodes for potentiometry, the use of silver and silver chloride seems to be considered the most suitable.

We employed graphite powder as a support of the $\mathrm{Ag} / \mathrm{AgCl}$ particles. Silver particles were obtained by reducing the silver ammonia complex with glucose as shown in chemical Eq. (3), while silver chloride particles were obtained by means of a precipitating agent.

The production of small particles (less than $500 \mathrm{~nm}$ in diameter) by electroless deposition depends on the concentration of reagents. On the one hand, a low concentration generates small particles, because there is not a sufficient number of particles to form a crystal. On the other hand, a high concentration yields small particles since many nucleation points are formed due to the fact that a very viscose medium has a higher friction coefficient. Thus, migration of particles is difficult and, consequently, particles do not agglomerate (Har- ris, 2007). The concentration of silver nitrate solutions used for the production of silver and silver chloride particles were respectively 8.0 and $0.4 \mathrm{~mol} \mathrm{~L}^{-1}$.

The size of a particle formed by electroless deposition can also be influenced by temperature since high temperatures provoke an agglomeration of the particles. We avoided the agglomeration of silver particles by electroless deposition by generating these particles at $283.15 \mathrm{~K}\left(10^{\circ} \mathrm{C}\right)$. Silver chloride particles were produced at room temperature, because no agglomeration was observed at this temperature.

The electroless deposition of silver yielded a metalized graphite powder. Silver particles produced by chemical synthesis are charged positively due to an excess of silver ions that adsorb on the silver surface. Since graphite particles have a negative charge (Sengupta et al., 2011), silver particles are attracted to their surface.

Silver chloride particles were deposited on graphite/silver powder using a lower concentration of silver nitrate since potassium chloride has a limited solubility in water $\left(3 \mathrm{~mol} \mathrm{~L}^{-1}\right)$. For silver nitrate concentrations higher than $0.4 \mathrm{~mol} \mathrm{~L}^{-1}$, the excess of silver ions in the solution adsorb onto the surface of the silver chloride particles provoking their agglomeration (Harris, 2007).

In our syntheses, the yield of silver particles and silver chloride particles varied between $60-84$ and $90-97 \%$, respectively. The particles of graphite/silver/silver chloride exhibited a grey colour with a content of silver chloride of about $40 \%$.

We manufactured quasi-reference electrodes using epoxy resin and hardener as the binder of the graphite particles/silver/silver chloride. Figure 1a shows the electrical behaviour of the quasi-reference electrodes against a conven- 

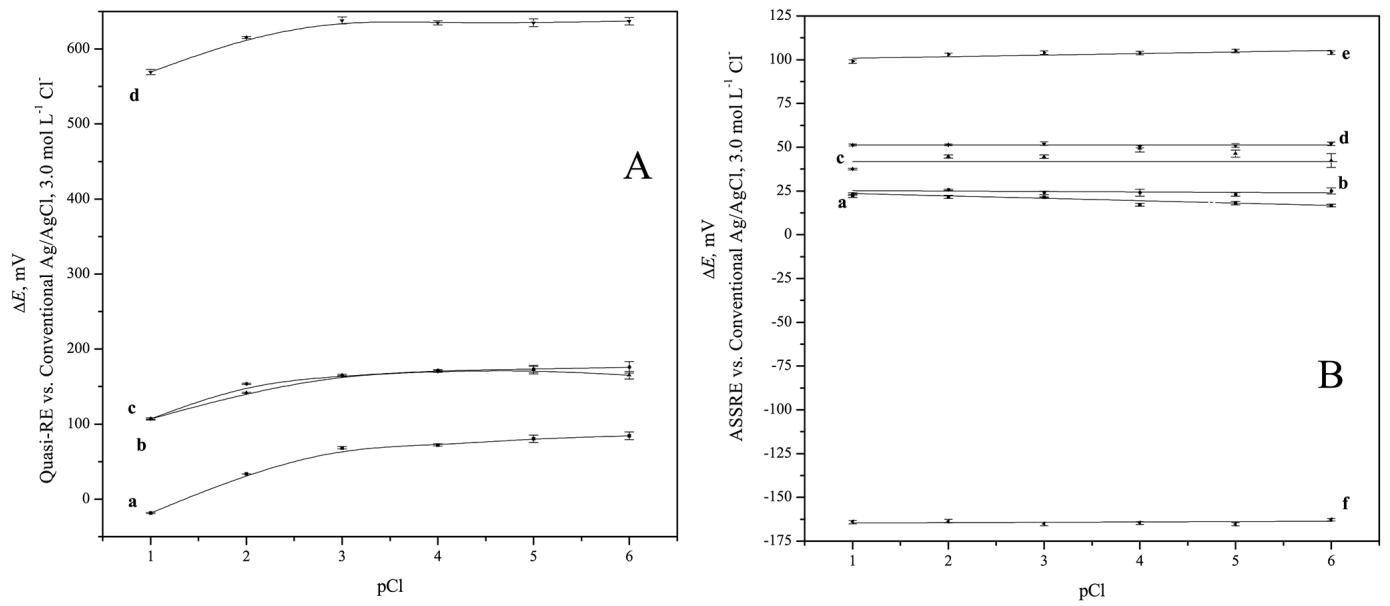

Figure 1. Potential measured with the quasi-reference electrodes (Quasi-RE) or all-solid-state reference electrodes (ASSREs) against a conventional reference electrode at room temperature. Curves obtained with (A) quasi-RE with an amount of $\mathrm{C}_{\text {graphite }} / \mathrm{Ag} / \mathrm{AgCl}$ particles in the paste equal to (a) $15 \% w / w$, (b) $30 \% w / w$, (c) $45 \% w / w$, and (d) BQ164 ink from Dupont; and (B) ASSREs containing the salts (a) $\mathrm{KCl}$, (b) $\mathrm{KCl}: \mathrm{SiO}_{2}$, (c) $\mathrm{BaCl}_{2}$, (d) $\mathrm{NaF}$, (e) $\mathrm{Na}_{2} \mathrm{SO}_{4}$, and (f) $\mathrm{KI}$.
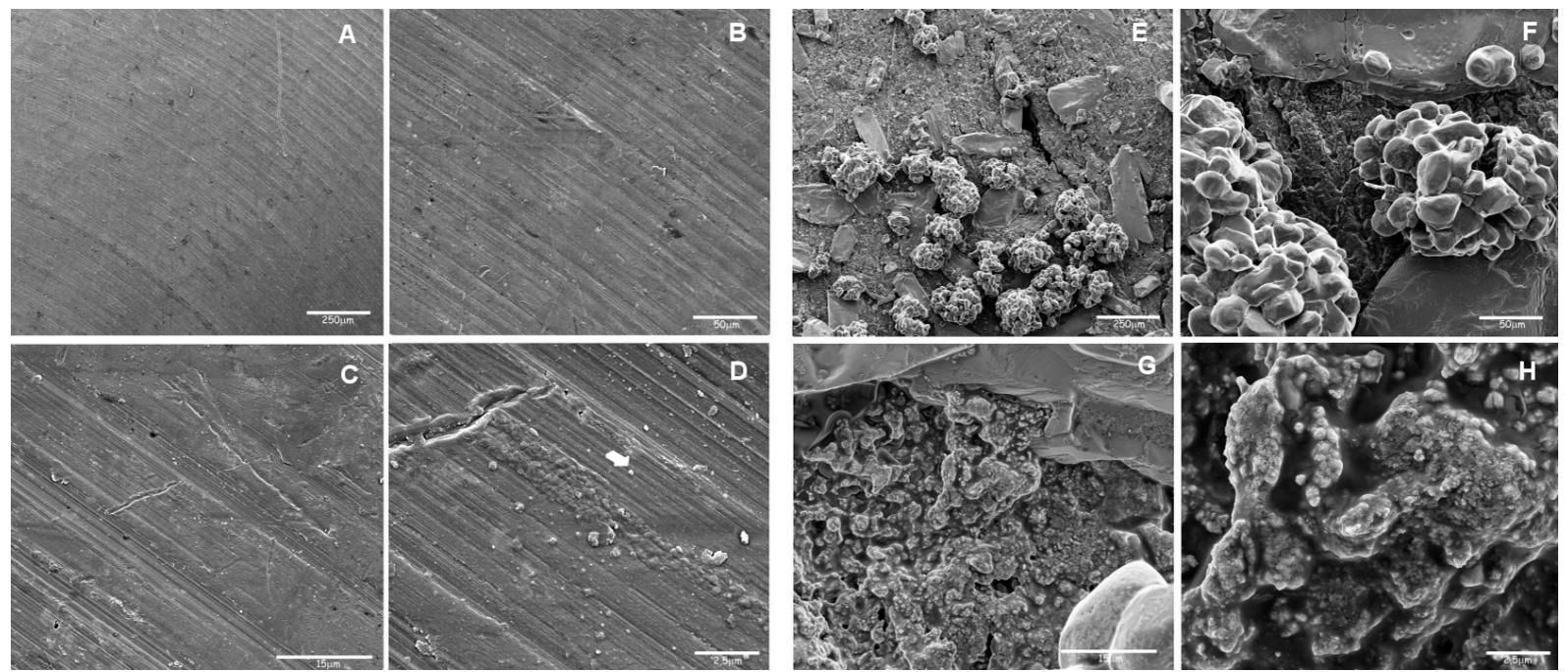

Figure 2. Surface photomicrographs of quasi- and all-solid-state reference electrodes containing $45 \% \mathrm{w} / \mathrm{w} \mathrm{C}_{\mathrm{graphite}} / \mathrm{Ag} / \mathrm{AgCl}$ (from a to d) and $3.0 \mathrm{~mol} \mathrm{~kg}^{-1} \mathrm{KCl}$ (from e to h), respectively. Magnifications are for (a) and (e) $200 \times$, (b) and (f) $1000 \times$, (c) and (g) $5000 \times$, and (d) and (h) $20000 \times$.

tional reference electrode in solutions with different chloride concentrations. The quasi-reference electrodes developed a potential change to concentration of chloride ions above $1 \times 10^{-3} \mathrm{~mol} \mathrm{~L}^{-1}$. Similar behaviour was obtained with reference electrodes made from BQ 164 ink.

Although quasi-reference electrodes have been employed in strips to measure glucose based on amperometric measurements (Matsumoto et al., 2002; Mamińska et al., 2006), these electrodes are not suited for use in potentiometric cells. The stability of the potential of a potentiometric cell must be independent of the concentration of chloride ions in the sample solution. Hence, the response only depends on the ion se- lective electrode. We added a high concentration of chloride ions, to overcome the problem of the quasi-reference electrodes, to the paste of graphite/silver/silver chloride mixed with epoxy resin and hardener. Any value between 1 and $3 \mathrm{~mol} \mathrm{~kg}^{-1}$ in the paste is acceptable because this concentration is about 10 times higher than the one found in real samples (whole blood, for example). Other anions such as sulfate, iodide, and fluoride were also studied. Figure $1 \mathrm{~b}$ shows the behaviour of these all-solid-state reference electrodes containing salts in their formulation.

The potential of the reference electrodes containing salts was maintained stable and constant to any concentration of 

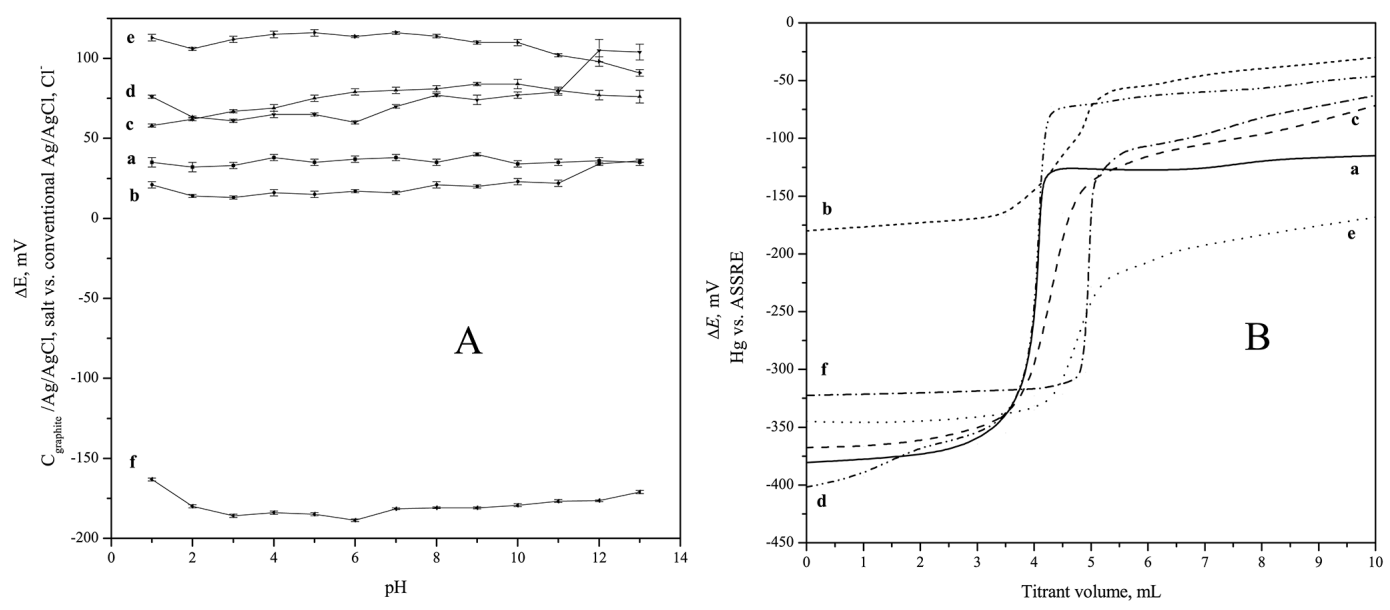

Figure 3. Influence of the $\mathrm{pH}$ and reducing agent on ASSREs. (A) Curves of $\mathrm{pH}$ obtained against ASSREs containing the salts (a) KCl, (b) $\mathrm{KCl}: \mathrm{SiO}_{2}$, (c) $\mathrm{BaCl}_{2}$, (d) $\mathrm{NaF}$, (e) $\mathrm{Na}_{2} \mathrm{SO}_{4}$, and (f) $\mathrm{KI}$. (B) Curves of potentiometric titration of L-ascorbic acid using indicator electrode of mercury against ASSREs. Titrant: $0.0125 \mathrm{~mol} \mathrm{~L}^{-1}$ copper (II) sulfate solution. Conditions and results: salts in ASSRE, mass of L-ascorbic acid titrated (in parenthesis), volume of titrant in the end-point and L-ascorbic acid content (\% w/w) found (in brackets). (a) $\mathrm{KCl}(9.1 \mathrm{mg}$ ) $4.102 \mathrm{~mL}$ [99\%], (b) $\mathrm{KCl}: \mathrm{SiO}_{2}$ (10.6 mg) $4.911 \mathrm{~mL}$ [102\%], (c) $\mathrm{BaCl}_{2}$ (10.1 mg) $4.484 \mathrm{~mL}$ [98\%], (d) $\mathrm{NaF}(9.2 \mathrm{mg}) 4.136 \mathrm{~mL}$ [99\%], (e) $\mathrm{Na}_{2} \mathrm{SO}_{4}(11.0 \mathrm{mg}) 4.800 \mathrm{~mL}$ [96\%], (f) $\mathrm{KI}(10.3 \mathrm{mg}) 4.901 \mathrm{~mL}$ [105\%]. The measurements were taken at room temperature.

Table 2. pH measured using a glass electrode against an all-solidstate reference electrode containing $1.5 \mathrm{~mol} \mathrm{~kg}^{-1} \mathrm{BaCl}_{2}$ at room temperature.

\begin{tabular}{rrrr}
\hline \multicolumn{3}{c}{$\mathrm{pH}$} \\
\hline $\begin{array}{r}\text { Nominal } \\
\text { value }\end{array}$ & $\begin{array}{r}\text { Combined } \\
\text { electrode }\end{array}$ & $\begin{array}{r}\text { Glass }(\mathrm{pH}) \text { vs. } \\
\mathrm{C}_{\text {graphite }} / \mathrm{Ag} / \mathrm{AgCl},\end{array}$ & $\begin{array}{r}\text { Relative error* } \\
1.5 \mathrm{~mol} \mathrm{~kg}^{-1} \mathrm{BaCl}_{2}\end{array}$ \\
\hline & & $1.85 \pm 0.08$ & $-1.6 \%$ \\
2.0 & $1.88 \pm 0.03$ & $3.00 \pm 0.07$ & $+1.0 \%$ \\
3.0 & $2.97 \pm 0.03$ & $4.11 \pm 0.06$ & $+2.0 \%$ \\
4.0 & $4.03 \pm 0.03$ & $5.12 \pm 0.04$ & $+0.8 \%$ \\
5.0 & $5.08 \pm 0.02$ & $6.11 \pm 0.03$ & $+1.8 \%$ \\
6.0 & $6.00 \pm 0.01$ & $7.19 \pm 0.02$ & $+1.0 \%$ \\
7.0 & $7.12 \pm 0.01$ & $8.22 \pm 0.01$ & $+0.9 \%$ \\
8.0 & $8.15 \pm 0.01$ & $9.09 \pm 0.01$ & $+2.3 \%$ \\
9.0 & $8.89 \pm 0.02$ & $10.19 \pm 0.01$ & $+1.8 \%$ \\
10.0 & $10.01 \pm 0.02$ & $11.35 \pm 0.03$ & $+0.9 \%$ \\
11.0 & $11.25 \pm 0.03$ & &
\end{tabular}

* Average of three determinations and standard deviation estimate.

chloride ions. The presence of silica in the paste did not influence the behaviour of the reference electrode containing potassium chloride. Figure $1 \mathrm{~b}$ reveals that all-solid-state reference electrodes containing other anions also kept a constant potential on the potentiometric cell. The potential change was lower than $5 \mathrm{mV}$ at chloride concentration changes from $1 \times 10^{-6}$ to $1 \times 10^{-1} \mathrm{~mol} \mathrm{~L}^{-1}$.

Figure 2 shows the surface photomicrographs of the reference electrodes obtained by means of scanning electronic microscopy. The white arrow in Fig. 2d illustrates the brilliant silver sub-particles on the surface of quasi-reference electrodes that presented diameters smaller than $2.5 \mu \mathrm{m}$. Figure 2 (from e to $\mathrm{h}$ ) also shows the presence of potassium chloride particles on the surface of the all-solid-state reference electrode.

Reference electrodes have to satisfy many requirements. These electrodes have to exhibit stable potential at changing $\mathrm{pH}$, redox species, complexing agents, salts and dissolved oxygen. Due to its importance for sterilization purposes, a high resistance to temperature and pressure is sometimes desirable too (Guth et al., 2009).

The effect of the $\mathrm{pH}$ on all-solid-state reference electrodes is shown in Fig. 3a. Silver ions may form a complex with hydroxyl ions poisoning the reference electrodes. The potential of the electrochemical cell was slightly affected in extreme regions of $\mathrm{pH}$, but the potential variation within the investigated $\mathrm{pH}$ range was lower than $15 \mathrm{mV}$. In these regions, factors such as liquid junction potentials and ionic strength are dependent on the $\mathrm{pH}$ and may have contributed to this problem (Feldman, 1956).

We applied the all-solid-state reference electrode containing $1.5 \mathrm{~mol} \mathrm{~kg}^{-1}$ of $\mathrm{BaCl}_{2}$ to measure $\mathrm{pH}$ using a glass electrode. The analytical performance is described by the following equation:

$\Delta E=(841 \pm 6)-(56.0 \pm 0.7) \mathrm{pH}$.

The potentiometric cell showed a linear response in the range of $\mathrm{pH}$ between 1.68 and 12.45 at $298.15 \mathrm{~K}\left(25^{\circ} \mathrm{C}\right)$. The correlation coefficient $(r)$ was 0.9997 for $n=5$. Table 2 shows the results obtained for the determination of $\mathrm{pH}$ using this potententiometric cell. The results were not significantly different when compared to a conventional combined glass electrode. The relative error was lower than $2.5 \%$. 

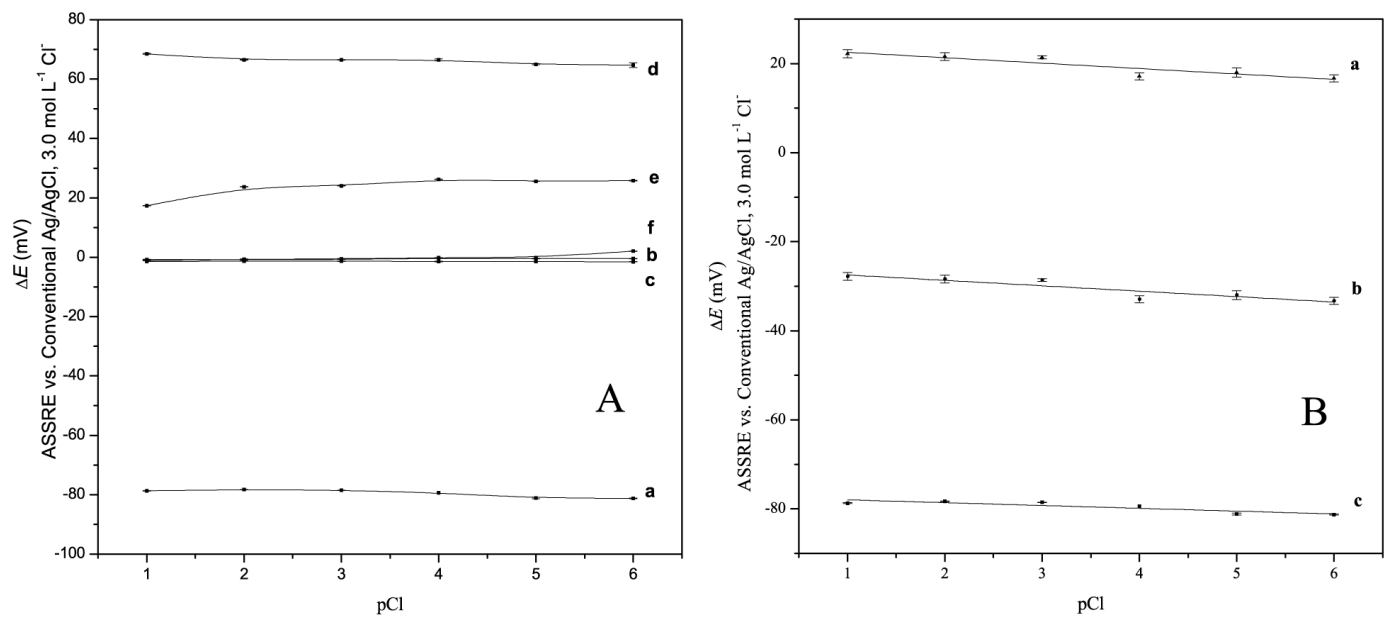

Figure 4. Behaviour of all-solid-state reference electrodes after the sterilization and diffusion process in deionized water during 20 days.

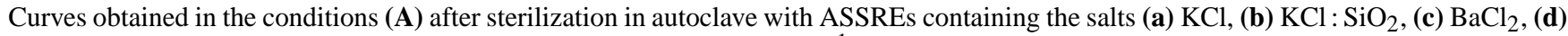
$\mathrm{NaF}$, (e) $\mathrm{Na}_{2} \mathrm{SO}_{4}$, and (f) $\mathrm{KI}$. (B) ASSREs containing $\mathrm{KCl}$ at $3.0 \mathrm{~mol} \mathrm{~kg}^{-1}$ (a) after sterilization, (b) after diffusion process, and (c) before everything.

Table 3. Results of the determination of potassium ions in real samples using an all-solid-state reference electrode containing $3.0 \mathrm{~mol} \mathrm{~kg}^{-1}$ $\mathrm{NaF}$ against ion-selective electrodes for potassium (ISE-K).

\begin{tabular}{rrrrr}
\hline Samples & $\begin{array}{r}\text { Nominal } \\
\text { value }\end{array}$ & $\begin{array}{r}\text { Flame photometry } \\
(\mathrm{mg})\end{array}$ & $\begin{array}{r}\text { Direct potentiometry } \\
\text { ISE-K vs. Cgraphite/Ag/AgCl, } \\
3.0 \mathrm{~mol} \mathrm{~kg}^{-1} \mathrm{NaF}\end{array}$ & $\begin{array}{r}\text { Relative } \\
\text { error } \\
(\%)\end{array}$ \\
\hline$\# 1$ & $18 \mathrm{mg} / 200 \mathrm{~mL}$ & $16 \pm 4^{\mathrm{a}}$ & $16 \pm 4^{\mathrm{b}}$ & $(-11) 0^{\mathrm{c}}$ \\
$\# 2$ & $50 \mathrm{mg} / 200 \mathrm{~mL}$ & $43 \pm 1$ & $48 \pm 2$ & $(-4)+12$ \\
$\# 3$ & $24 \mathrm{mg} / 200 \mathrm{~mL}$ & $22.9 \pm 0.3$ & $20 \pm 1$ & $(-16)-13$ \\
$\# 4$ & $44 \mathrm{mg} / 200 \mathrm{~mL}$ & $40 \pm 1$ & $46 \pm 5$ & $(+4)+15$ \\
$\# 5$ & $60 \mathrm{mg} / \mathrm{mL}$ & $51 \pm 1$ & $56 \pm 8$ & $(-7)+10$ \\
$\# 6$ & $100 \mathrm{mg} / 5 \mathrm{~mL}$ & $90 \pm 3$ & $99 \pm 13$ & $(-1)+10$
\end{tabular}

Sample composition: noncarbonated sports drinks - \#1: water, sucrose, potassium dihydrogen phosphate, sodium chloride, citric acid, sodium citrate, natural tangerine flavour, dimethyl carbonate (preservative), calcium disodium EDTA, sunset yellow dye and tartrazine dye. \#2: water, sucrose, potassium dihydrogen phosphate, sodium chloride, magnesium sulfate, calcium phosphate, citric acid, sodium benzoate, potassium sorbate, sodium citrate, acacia gum, calcium disodium EDTA and ester gum. \#3: water, sucrose, glucose, potassium dihydrogen phosphate, sodium chloride, citric acid, flavouring, sodium citrate, 40 red dye and sunset yellow dye. \#4: water, sucrose, potassium dihydrogen phosphate, sodium chloride, citric acid, sodium benzoate, potassium sorbate, arabic gum, natural carambole flavour, sodium citrate, sunset yellow dye, ascorbic acid and calcium disodium EDTA. Syrups; \#5: water, potassium chloride, sodium cyclamate, sodium saccharin dihydrate, methylparaben, propylparaben, propylene glycol, hydroxyethyl cellulose, sorbitol, cherry essence and riboflavin phosphate sodium. \#6: water, potassium iodide, sodium cyclamate, sodium saccharin, parabens, ethyl alcohol, sorbitol, mint essence, red dye and lobelia extract. ${ }^{a}$ Average of three determinations and standard deviation estimate. ${ }^{b}$ Calculated by error propagation. ${ }^{c}$ Relative error between direct potentiometry and nominal value (parenthesis) or direct potentiometry and flame photometry.

Another all-solid-state reference electrode was applied to measure potassium ions using an ion selective electrode based on valinomycin as ionophore. Potassium ions were determined by direct potentiometry in real samples of noncarbonated sports drinks and syrups using an all-solid-state reference electrode containing fluoride ions since this anion was not present in the samples. Table 3 shows these results compared to flame photometry. The samples presented a complex matrix containing salts, EDTA, dyes and other substances that could affect the all-solid state reference electrode. However, this effect was not observed. The obtained results by direct potentiometry agree with those determined by flame photometry within an acceptable band of deviation.

We also applied the all-solid-state reference electrodes to the potentiometric titration of L-ascorbic acid using an indicator electrode of mercury (Fig. 3b). L-ascorbic acid is a reducing agent, unstable in solutions with $\mathrm{pH}$ higher than 5.0 and easily oxidized by metallic ions (Fernandes et al., 1999). Hence, L-ascorbic acid could affect the all-solid-state reference electrodes. We determined L-ascorbic content in pure reagent equal to $100 \pm 3 \% \mathrm{w} / \mathrm{w}$. Therefore, the influence of the redox process between L-ascorbic acid and copper (II) 
ions was not observed on the all-solid state reference electrodes.

The all-solid-state reference electrodes were tested for sterilization in autoclave (Fig. 4a). The reference electrodes were fully functional after sterilization. However, we observed that the potential of these electrodes differed from the one measured before sterilization. We believed that this effect occurred due to a change in the structure of the composite, with migration of salt particles to the surface. This hypothesis was based on the observation of a white powder on the surface of the electrodes after sterilization, but the potential was independent of the chloride ions concentration.

The leaching out effect of the salt was studied with allsolid-state reference electrodes containing $3.0 \mathrm{~mol} \mathrm{~kg}^{-1} \mathrm{KCl}$ submitted to a diffusion process in deionized water for 20 days. We examined this water by means of a silver nitrate solution and we observed the formation of silver chloride precipitate $(4.1 \mathrm{mg})$, which corresponds to $2.1 \mathrm{mg}$ of potassium chloride. Every day, about $0.18 \%$ of potassium chloride was leached out of the reference electrode. This reference electrode was re-examined in a new potentiometric cell with a commercial reference electrode to measure chloride ions (from $10^{-6}$ to $10^{-1} \mathrm{~mol} \mathrm{~L}^{-1}$ ). Comparing the measures, before and after of the diffusion process, we observed a potential-drift of about $50 \mathrm{mV}$ (Fig. 4). Despite the loss of the chloride ions, this all-solid state reference electrode maintained a constant potential of the potentiometric cell to all range of chloride ions concentration. Therefore, this kind of electrode must be stored in dry conditions.

\section{Conclusions}

All-solid-state reference electrodes based on particles of graphite/silver/silver chloride, salts and epoxy resin showed good operational characteristics for potentiometry. The potential was stable and independent of any chloride ions concentration. These electrodes were not sensitive to abrasion, redox species, $\mathrm{pH}$ and high-pressure saturated steam at $394.15 \mathrm{~K}\left(121^{\circ} \mathrm{C}\right)$. Moreover, they can be miniaturized easily by thick film technology since the components can be transformed into an ink.

The strategy of manufacturing by electroless deposition of silver and silver chloride particles on graphite powder is a simple and efficient methodology and does not require the use of a potentiostat.

The results for measuring potassium ions and $\mathrm{pH}$ by direct potentiometry or L-ascorbic acid by potentiometric titration indicate that the proposed methodology for manufacturing all-solid-state reference electrodes is very promising.

Author contributions. J. C. B. Fernandes designed the experiments and E. V. Heinke carried them out. J. C. B. Fernandes prepared the manuscript with contributions from all co-authors.
Acknowledgements. This research was supported in part by FAPESP (2007/556277 process) and by USCS in terms of a scholarship to E. V. Heinke. We thank the Centre of Electronic Microscopy from UNIFESP (hhtp://www.unifesp.br/centros/ceme/links.htm) for obtaining photomicrographs. We also thank Denise O. Alonso, USCS, and Peter Sussner, UNICAMP, for the English revision.

Edited by: A. Schütze

Reviewed by: three anonymous referees

\section{References}

Cha, G. S., Cui, G., Yoo, J., Lee, J. S., and Nam, H.: Planar reference electrode. U.S. Patent 6,964,734 B2, 2005.

Feldman, I.: Use and Abuse of pH Measurements, Anal. Chem., 28, 1859-1866, 1956.

Fernandes, J. C. B., Kubota, L. T., and Neto, G. O.: Potentiometric sensor for L-ascorbic acid based on EVA membrane doped with copper (II), Electroanal., 11, 475-480, 1999.

Fernandes, J. C. B., Neto, G. O., Rohwedder, J. J. R., and Kubota, L. T.: Simultaneous determination of chloride and potassium in carbohydrate electrolyte beverages using an array of ion-selective electrodes controlled by a microcomputer, J. Braz. Chem. Soc., 11, 349-354, 2000.

Guth, U., Gerlach, F., Decker, M., Oelßner, W., and Vonau, W.: Solid-state reference electrodes for potentiometric sensors, J. Solid State Electrochem., 13, 27-39, 2009.

Harris, D. C.: Quantitative Chemical Analysis, 7th Edn., WH Freeman and Company, New York, 2007.

Janz, G. J. and Taniguchi, H.: The silver-silver halide electrodes, Chem. Rev., 3, 397-437, 1953.

Jayaweera, P., Passel, T. O., and Millett, P. J.: Solid state reference electrode for high temperature electrochemical measurements, U.S. Patent 5,425,871, 1995.

Koura, N.: Electroless plating of silver, in: Electroless plating: Fundamentals \& Applications, edited by: Mallory, G. O. and Hadju, J. B., 1st Edn., American Electroplaters and Surface Finishers Society, Florida, 441-462, 1990.

Mamińska, R., Dybko, A., and Wróblewski, W.: All-solid-state miniaturised planar reference electrodes based on ionic liquids, Sens. Actuators B, 115, 552-557, 2006.

Matsumoto, T., Ohashi. A., and Ito, N.: Development of a microplanar $\mathrm{Ag} / \mathrm{AgCl}$ quasi-reference electrode with long-term stability for an amperometric glucose sensor, Anal. Chim. Acta, 462, 253-259, 2002.

Rius-Ruiz, F. X., Kisiel, A., Michalska, A., Maksymiuk, K., Riu, J., and Rius, F. X.: Solid-state reference electrodes based on carbon nanotubes and polyacrylate membranes, Anal. Bioanal. Chem., 399, 3613-3622, 2011.

Riyazuddin, P. and Nazer, M. M. A. K.: Potentiometric determination of ascorbic acid in pharmaceutical preparations using a copper based mercury film electrode, J. Pharm. Biomed. Anal., 16, 545-551, 1997.

Rodes, M. L.: Solid state reference electrode, U.S. Patent 7,318,887 B2, 2008.

Sengupta, R., Bhattacharya, M., Bandyopadhyay, S., and Bhowmicka, A. K.: A review on the mechanical and electrical properties of graphite and modified graphite reinforced polymer composites, Prog. Polym. Sci., 36, 638-670, 2011. 
Shin, J. H., Lee, S. D., Nam, H., Cha, G. S., and Bae, B. W.: Miniaturized solid-state reference electrode with self-diagnostic function, US Patent 6,554,982B1, 2003.

Sorensen, P. R. and Zachau-Christiansen, B.: Electrode device with a solid state reference system, U.S. Patent 2004/0163949 A1, 2004.

Suzuki, H., Hirakawa, T., Sasaki, S., and Karube, I.: Micromachined liquid-junction $\mathrm{Ag} / \mathrm{AgCl}$ reference electrode, Sens. Actuators B, 46, 146-154, 1998.

Suzuki, H., Shiroishi, H., Sasaki, S., and Karube, I.: Microfabricated liquid junction $\mathrm{Ag} / \mathrm{AgCl}$ reference electrode and its application to a one-chip potentiometric sensor, Anal. Chem., 71, 5069-5075, 1999.
Tymecki, L., Zwierkowska, E., and Koncki, R.: Screen-printed reference electrodes for potentiometric measurements, Anal. Chim. Acta, 526, 3-11, 2004.

Valdés-Ramírez, G., Ramírez-Silva, M. T., Palomar-Pardavé, M., Romero-Romo, M., Álvarez-Romero, G. A., HernándezRodríguez, P. R., Marty, J. L., and Juárez-García, J. M.: Design and construction of solid state $\mathrm{Ag} / \mathrm{AgCl}$ reference electrodes through electrochemical deposition of $\mathrm{Ag}$ and $\mathrm{AgCl}$ onto a graphite/epoxy resin-based composite. Part 1: Electrochemical deposition of $\mathrm{Ag}$ onto a graphite/epoxy resin-based composite, Int. J. Electrochem. Sci., 6, 971-987, 2011.

Weast, R. C.: Handbook of Chemistry and Physics, 78th edition, CRC Press, Boca Raton, 1998. 